MINERAL OCCURRENCES NEAR CANTWELL, SOUTH-CENTRAL ALASKA

By

Robert G. Hickman and Campbell Craddock

SPECIAL REPORT 13

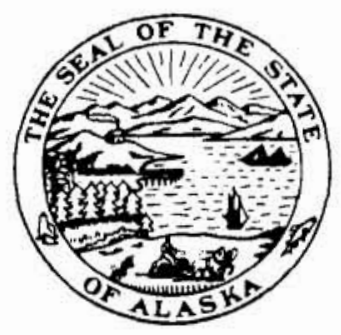




\section{STATE OF ALASKA}

Jay S. Hammond, Governor

Guy R. Martin, Commissioner, Dept. of Natural Resources

Ross G. Schaff, State Geologist

For sale by Alaska Division of Geological and Geophysical Surveys, P.o. Box 80007, College, 99701: 323 E. 4th Ave., Anchorage, 99501: P.O. Box 2438, Ketchikan, 99901; and Pouch M, Juneau, 99811 - Price $\$ 1.00$. 


\section{CONTENTS}

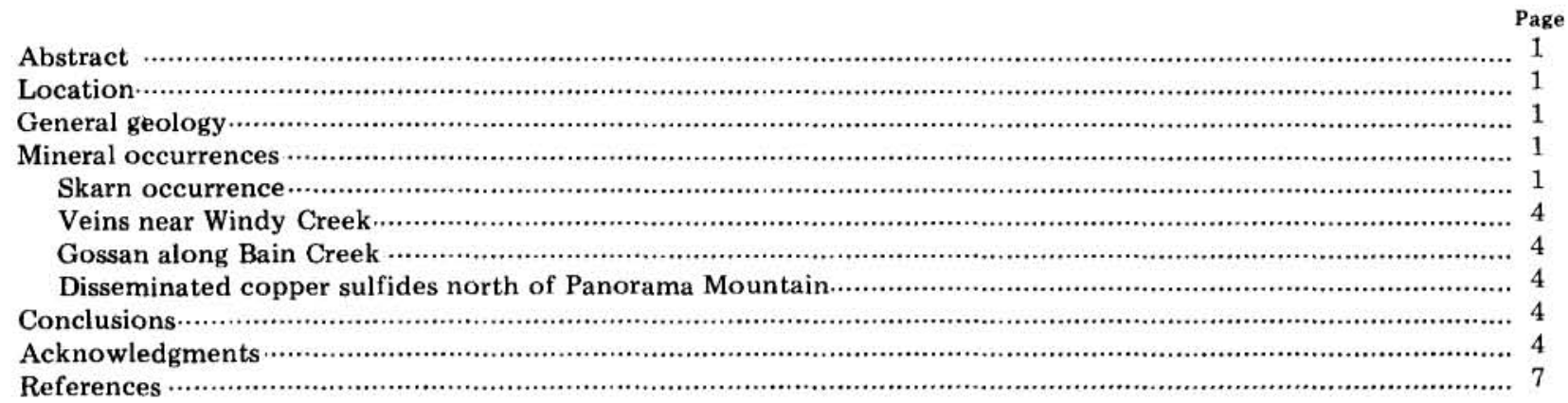

\section{ILLUSTRATIONS}

FIGURE 1. Outline map showing location of Healy quadrangle .........................................................

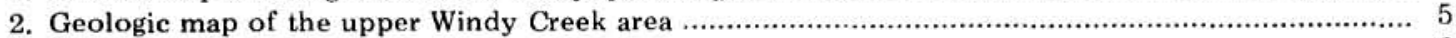

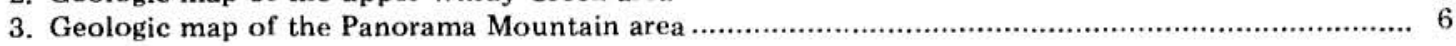

\section{TABLES}

TABLE 1. Atomic-absorption spectrophotometric analyses of specimens from upper

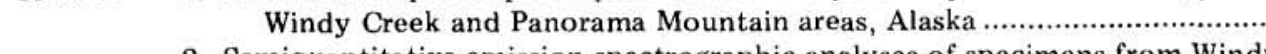

Page

2. Semiquantitative-emission spectrographic analyses of specimens from Windy

Creek and Panorama Mountain areas, Alaska 


\title{
MINERAL OCCURRENCES NEAR CANTWELL, SOUTH-CENTRAL ALASKA
}

\author{
By Robert G. Hickman and Campbell Craddock
}

\begin{abstract}
Regional geologic mapping, conducted as part of a continuing investigation of the Denali Fault system, has revealed several small areas of mineralization in the central Alaska Range near Cantwell, Alaska. These occurrences are not known to have been previously reported. This paper provides a brief description of these mineralized areas.
\end{abstract}

\section{LOCATION}

The Alaska Range forms an arc, convex to the north, extending from the Yukon Territory border westward to the Alaska Peninsula. The area treated in this report is within the west-central part of the USGS 1:250,000 Healy quadrangle and is located on the southern flank of the Alaska Range, near the apex of the arc formed by the range (fig. 1). Access to the area from Anchorage or Fairbanks is provided by the Alaska Railroad and by Alaska Highway 3 ; both parallel the Nenana River where it crosses the Alaska Range.

\section{GENERAL GEOLOGY}

The areal geology of parts of western Healy quadrangle has been described by Moffit (1915), Capps (1932, 1940), Wahrhaftig (1958), Wahrhaftig and Black (1958), Moxham and others (1959), and Hickman $(1971,1974)$ and is summarized below.

The principal structural feature of the central Alaska Range is a segment of the Denali Fault system, a major tectonic feature of southern Alaska. Several authors have suggested that the Denali Fault system is a dextral strike-slip structure with a large lateral displacement (St. Amand, 1954, 1957; Grantz, 1966; Richter and Jones, 1973; Forbes and others, 1973; and Reed and Lanphere, 1974). In the central Alaska Range, the fault system consists of two strands, about 20 miles apart. Near Cantwell, the southern (McKinley) strand strikes about $\mathrm{N} 70^{\circ} \mathrm{E}$ and divides the area of this report into two terranes (Grantz, 1966).

The terrane north of the McKinley fault consists of a thick sequence of Phanerozoic sedimentary and volcanic rocks. Within the area of this report, these strata include: 1) pre-Devonian argillite; 2) Devonian gray wacke, argillite, conglomerate, and limestone; 3) Permian or
Pennsylvanian(?) argillite, gray wacke and mafic volcanic rocks; 4) Triassic sandstone, conglomerate, and limestone; and 5) Paleocene sandstone, conglomerate, and shale of the Cantwell Formation. Intrusive igneous rocks include Mesozoic(?) gabbro sills, and Cenozoic and Mesozoic felsic stocks and sills. Immediately south of the McKinley fault, the second terrane consists of: 1) Devonian(?) slate and limestone; and 2) Jurassic or Cretaceous (or both) argillite, conglomerate, and gray wacke.

Both terranes have a strong east-west structural grain. Within the map area, minor faults commonly parallel the trend of the McKinley fault. Both to the north and south of the McKinley strand, beds are strongly folded, and fold axes trend east to northeast.

North of the McKinley Strand, structural relationships indicate one or more periods of pre-Cenozoic folding, strong early Tertiary folding, and gentle late Tertiary folding. In the terrane south of the fault, evidence suggests periods of folding during: 1) the Paleozoic, 2) the late Mesozoic or early Tertiary, and 3) the late Tertiary.

\section{MINERAL OCCURRENCES}

The mineral occurrences which were noted in the course of mapping include:

1) Skarn depusits in the upper Windy Creek basin.

2) Pyritized and silicified sedimentary rocks cut by small stibnite-sphalerite veins near Windy Creek.

3) A gossan associated with a brecciated felsic dike along Bain Creek.

4) Minor amounts of disseminated bornite and digenite in mafic volcanic rocks north of Panorama Mountain.

The first three of these occurrences are a short distance inside the eastern boundary of Mount McKinley National Park. The fourth occurrence is about 1 mile east of the park boundary. Elemental analyses for specimens collected at these occurrences are keyed to the map localities and are listed in tables 1 and 2 .

\section{SKARN OCCURRENCE (MAP LOCALITIES $1 \&$ 2)}

Skarn mineralization occurs near the contact of a small quartz-diorite stock with Devonian limestone and 


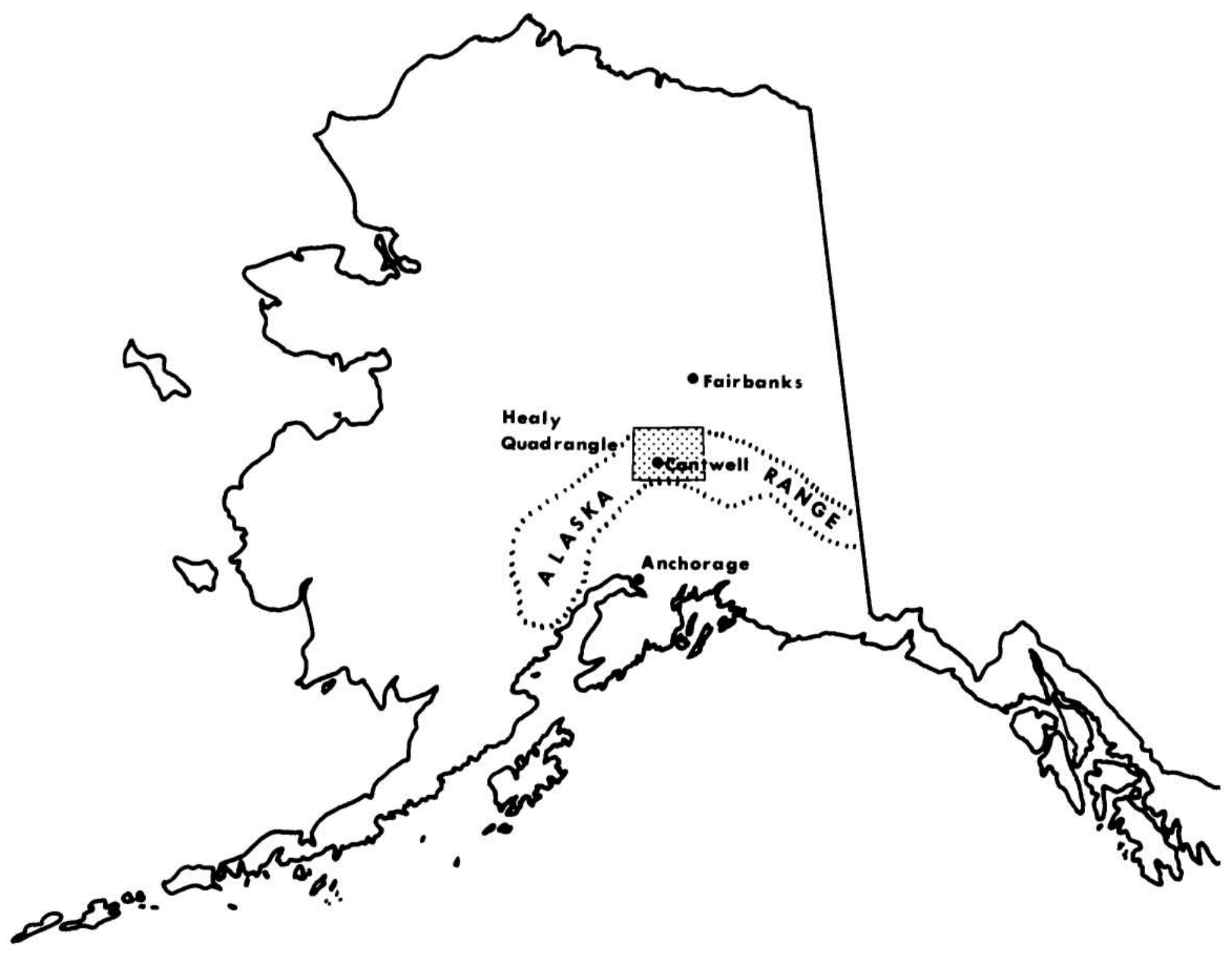

Figure 1. Location of Healy quadrangle. 
Table 1. Atomic-absorption spectrophotometric analyses of specimens from upper Windy Creek and Panorama Mountain area, Alaska. ${ }^{1}$

\begin{tabular}{|c|c|c|c|c|c|c|c|c|}
\hline Map & Field & $\begin{array}{c}\text { Copper } \\
(\mathrm{ppm})\end{array}$ & $\begin{array}{l}\text { Lead } \\
\text { (ppm) }\end{array}$ & $\begin{array}{l}\text { Zinc } \\
\text { (ppm) }\end{array}$ & $\begin{array}{l}\text { Silver } \\
\text { (ppm) }\end{array}$ & $\begin{array}{l}\text { Gold } \\
\text { (ppm) }\end{array}$ & $\begin{array}{l}\text { Nickel } \\
\text { (ppm) }\end{array}$ & Remarks \\
\hline 1 & UW/1574-9 & 1900 & 21 & 52 & 0.6 & $\mathrm{ND}^{2}$ & 7 & Limonitic pyrrotite and minor chalcopyrite. \\
\hline 2 & $\mathrm{UW} / 1574-10$ & 1900 & 5 & 17 & 0.8 & ND & 31 & . do $\cdots$ d. \\
\hline 3 & UW/1574-8 & 27 & 8800 & 2200 & 14.9 & ND & 5 & $\begin{array}{l}\text { Vein material containing stibnite and } \\
\text { sphalerite. }\end{array}$ \\
\hline 4 & UW/1574-34 & 69 & 16 & 76 & 0.7 & ND & 13 & $\begin{array}{l}\text { Brecciated dike material cemented by iron } \\
\text { oxides. }\end{array}$ \\
\hline
\end{tabular}

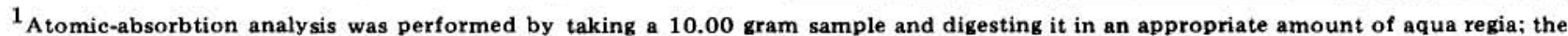
digestate was diluted to 100 milliliters with distilled $\mathrm{H}_{2} \mathrm{O}$ and centrifuged. The elements copper, lead, zinc, silver, and nickel were aspirated directly into an air-acetylene flame; gold was determined following a DIBK-Aliquot 336 solvent-solvent extraction. Opticalemission spectrographic analyses of all samples were performed using a 1.5-meter Wadsworth mounted Jarrell-Ash DC-arc emission spectrograph.

$2_{\mathrm{ND}}=$ looked for but not detected.
}

Table 2. Semiquantitative-emission spectrographic analyses of specimens from upper Windy Creek and Panorama Mountain areas, Alaska. ${ }^{1}$

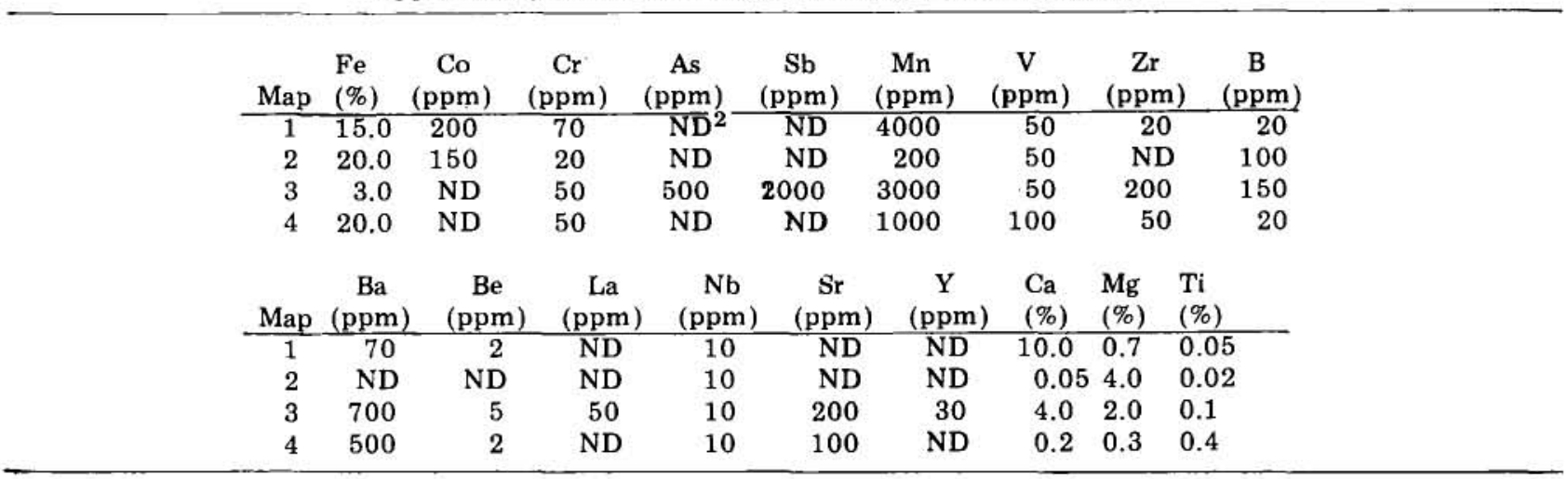

${ }^{1}$ Mo, W, Cd, Bi, Sn, and Sc were looked for but not detected.

$2 \mathrm{ND}=$ looked for but not detected. 
argillite (fig. 2). The stock and the contact zone are poorly exposed. Limestone near the skarn contains the metamorphic assemblage calcite-wollastonite-diopside. The skarn appears to form a steeply dipping, irregular zone 3 to 9 feet wide, and consists chiefly of dark. brown garnet and magnetite. Discontinuous 1- to 3-footwide zones of pyrrhotite and minor chalcopyrite occur with the skarn and as isolated masses along fracture zones (locality 1). The sulfide minerals are heavily coated by limonite, and locally are stained by malachite and ery thrite.

The quartz diorite is fine to medium grained and has a hypidiomorphic-granular texture. A point count of a single thin section yielded the following modal composition:

\begin{tabular}{lcc} 
UW 1574/32 & & Content $(\%)$ \\
\cline { 1 - 1 } Plagioclase & & $58-$ An $_{24-25}$ reverse zoning \\
Orthoclase & & $5-$ Interstitial \\
Quartz & & $24-$ In part secondary \\
Hornblende & & 7 \\
Clinopyroxene & & 2 \\
Opaque minerals & & 1 \\
Chlorite & 1 \\
Calcite & & 2 \\
Apatite & Trace \\
Zircon & Trace
\end{tabular}

Plagioclase in this specimen (UW 1574/32) is moderately sericitized, and the quartz diorite typically has an altered appearance. However, no mineralization was noted in the quartz diorite.

The stock is tentatively considered to be of Tertiary or late Mesozoic age because of the numerous felsic intrusions of this age in the region. However, the stock might be genetically related to the Mesozoic(?) gabbros that are widespread in the Windy Creek area. The contact between the stock and the Permian or Pennsylvanian rocks to the north is not exposed.

\section{VEINS NEAR WINDY CREEK (MAP LOCALITY 3)}

About 1.5 miles east of locality 2 is a small area of silicified and pyritized sedimentary rocks (fig. 2). These rocks, which are considered to be part of the Permian or Pennsylvanian(?) sequence, are cut by a few small (0.2- to 1-inch) veinlets of stibnite, sphalerite, and pyrite. The extent of the mineralized area is not known, but it appears to extend for at least 150 feet along the south side of a tributary of Windy Creek. Access is hampered by a thick growth of willows and alders along the stream. This mineralization may be genetically related to the quartz diorite stock to the west, or to an unexposed felsic intrusion.

\section{GOSSAN ALONG BAIN CREEK (MAP LOCALITY 4)}

Between Little Windy Creek and Bain Creek, a dike of porphyritic rhyolite or dacite lies roughly parallel to and near the Bain Creek fault (fig. 2). Near Bain Creek, the dike appears to be cut off by the fault, and the dike material is highly brecciated. This material is strongly altered, and the dike is marked by a yellowish-brown gossan. Breccia fragments are equant to platy and are 0.5 to 1.5 inches in diameter. The fragments are cemented by limonite.

This locality was examined only briefly and the extent of the brecciated rock is not known. No sulfide minerals were noted in the altered dike material or in the gossan.

\section{DISSEMINATED COPPER SULFIDE NORTH OF PANORAMA MOUNTAIN (MAP LOCALITY 5)}

Approximately 2 miles north of Panorama Mountain is a small area of altered, light-green basalt or andesite (fig. 3). Bornite and digenite occur as irregularly intergrown 0.05 - to 0.2 -inch grains within this greenstone. The total amount of sulfides in the greenstone is small, probably less than 1 percent. This small area of greenstone is on strike with more extensive exposures of greenstone to the east-greenstones that include pillowed flows and possibly subaqueous flow breccias. All of these greenstones are believed to be of Permian or Pennsylvanian age because of productid brachipods found within interbedded sedimentary rocks a few miles to the west (Hickman, 1974).

Disseminated copper sulfides were not noted in the more extensive greenstone exposures to the east, or in similar exposures to the west and near Panorama Mountain. However, a few coatings of malachite in these areas suggest that minor amounts of copper sulfides probably are present.

\section{CONCLUSIONS}

All of the described mineralization appears to be low grade and of limited areal extent. However, because the localities were examined only briefly (and because some of those were poorly exposed), the occurrences may merit additional examination. The localities are significant in that they (1) indicate that mineralization occurs within the area, and (2) suggest the geologic settings in which economic deposits may occur. The occurrences suggest that exploration in the area should be centered on (1) felsic intrusions, (2) Paleozoic volcanic flows and breccias, and (3) fault and fracture zones.

\section{ACKNOWLEDGMENTS}

Support for this research was furnished through National Science Foundation Grant GA-28966 and a University of Wisconsin Graduate School grant to Campbell Craddock. The atomic-absorbtion analyses were performed by T.C. Trible of DGGS. Optical 


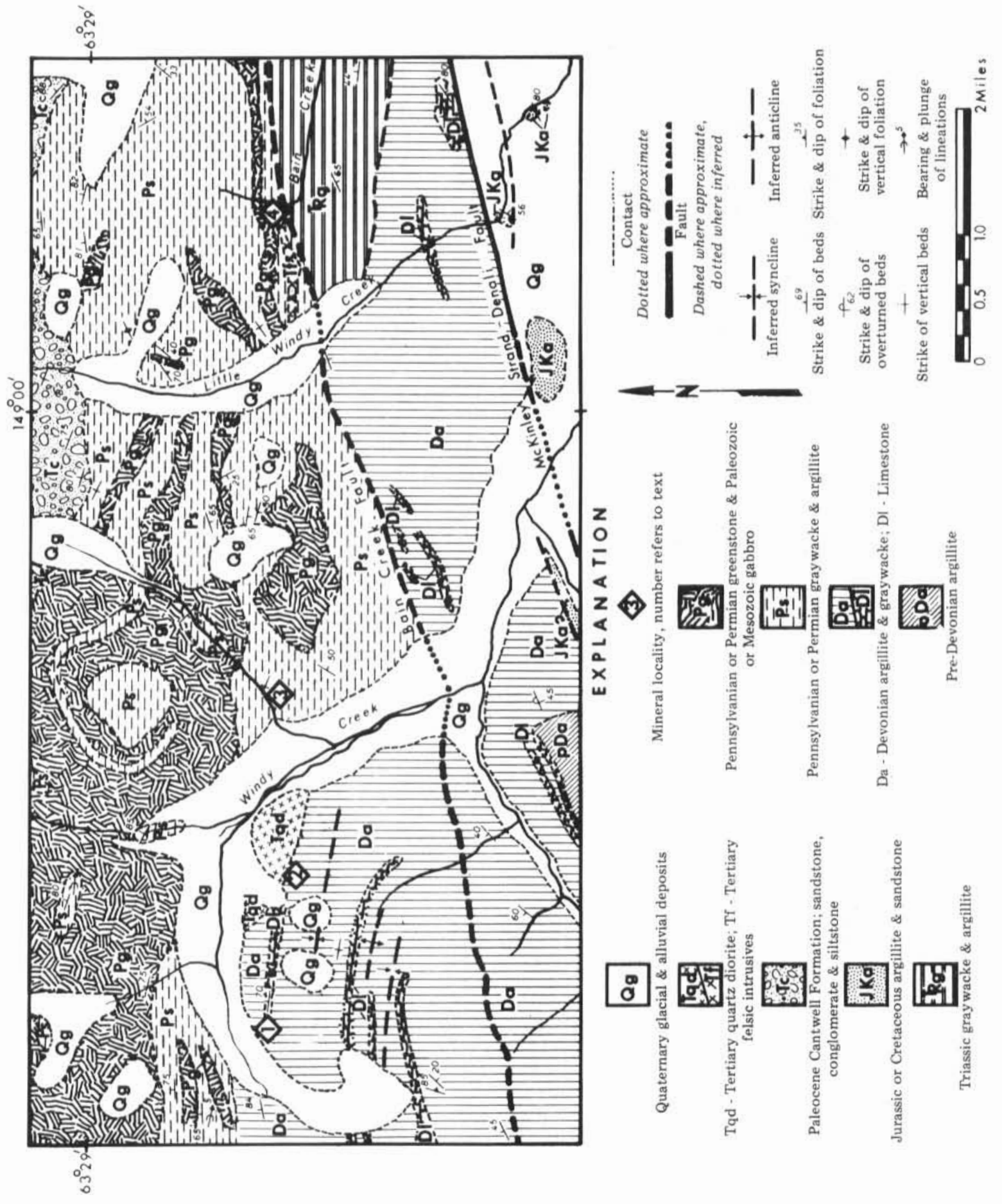

Figure 2. Geologic map of the upper Windy Creek area. 


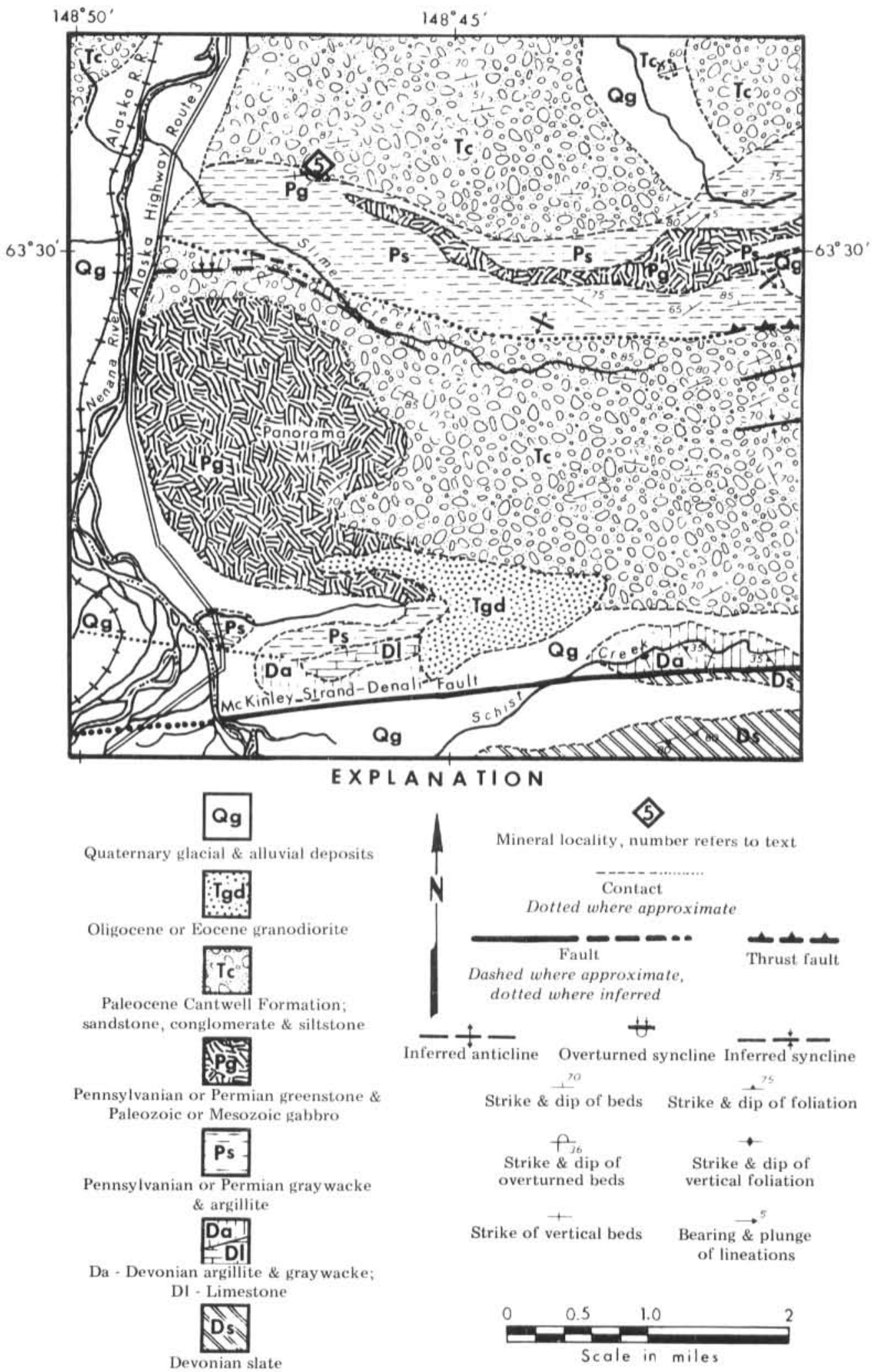

Figure 3. Geologic map of the Panorama Mountain area. 
emission spectrographic analysis of the samples was carried out by Spe Comp Services, Inc. of Steamboat Springs, Colorado. We also wish to thank T.E. Smith, formerly with DGGS, for his interest and encouragement and for arranging to have samples analyzed in the DGGS laboratory.

\section{REFERENCES}

Capps, S.R., 1932, The eastern portion of Mt. McKinley National Park: U.S. Geol. Survey Bull. 836-D, p. 219300 .

, 1940, Geology of the Alaska Railroad region: U.S. Geol. Survey Bull, 907, 201 p.

Forbes, R.B., Turner, D.L., Stout, J.H., and Smith, T.E., 1973, Cenozoic offset along the Denali Fault, Alaska [abs.] : Trans. Am. Geophys. Union, v. 54, p. 495.

Grantz, A., 1966, Strike-slip faults in Alaska: U.S. Geol. Survey open-file rept., $82 \mathrm{p}$.

Hickman, R.G., 1971, The Denali Fault near Cantwell, Alaska: M.S. thesis, Univ. of Wisconsin, 76 p. 1974 , Structural geology and stratigraphy along a segment of the Denali Fault system, central Alaska Range, Alaska: Ph.D. thesis, Univ. of Wisconsin, $276 \mathrm{p}$.
Moffit, F.H., 1915, The Broad Pass region, Alaska: U.S. Geol. Survey Bull. 608, 80 p.

Moxham, R.M., Eckhart, R.A., and Cobb, E.H., 1959, Geology and cement raw materials of the Windy Creek area, Alaska: U.S. Geol. Survey Bull. 1039-D, p. $67-100$.

Reed, B.L., and Lanphere, M.A., 1974, Offset plutons and history of movement along the McKinley segment of the Denali Fault system, Alaska: Geol. Soc. America Bull., v. 85, p. 1883-92.

Richter, D.H., and Jones, D.L., 1973, Structure and stratigraphy of the eastern Alaska Range, in Arctic Geology (M.G. Pitcher, ed.): Am. Assoc. Petroleum Geologists Mem. 19, p. 408-420.

St. Amand, P., 1954, Tectonics of Alaska as deduced from seismic data: Geol. Soc. America Bull., v. 65, p. 1350 .

, 1957, Geological and geophysical synthesis of the tectonics of portions of British Columbia, the Yukon Territory and Alaska: Geol. Soc. America Bull., v. 68, p. 1343-1370.

Wahrhaftig, C., 1958, Quaternary geology of the Nenana River valley and adjacent parts of the Alaska Range: U.S. Geol. Survey Prof. Paper 293-A, 68 p.

Wahrhaftig, C., and Black, R.F., 1958, Engineering geology along part of the Alaska Railroad: U.S. Geol. Survey Prof. Paper 293-B, p. 69-118. 